BARBARA JANKOWIAK

Uniwersytet im. Adama Mickiewicza

$w$ Poznaniu

\title{
KONFLIKT MIĘDZY RODZICAMI JAKO CZYNNIK RYZYKA NIEPRZYSTOSOWANIA DZIECI I MŁODZIEŻY
}

ABSTRACT. Jankowiak Barbara, Konflikt między rodzicami jako czynnik ryzyka nieprzystosowania dzieci i młodzieży [Parental Conflict as a Risk Factor of Maladjustment in Children and Adolescents]. Studia Edukacyjne nr 36, 2015, Poznań 2015, pp. 165-178. Adam Mickiewicz University Press. ISBN 978-83232-2958-2. ISSN 1233-6688. DOI: 10.14746/se.2015.36.10

The aim of the article is to analyze parental conflict as a risk factor of difficulties experienced by their children. Research studies have shown that parental conflict is connected with maladjustment, defined as internalizing and externalizing problems. The difficulties experienced by children contribute to a deepening of the conflict between partners, especially in the field of parenting. The research cited proves that children and adolescents in families with conflicts and arguments should be given psychological and pedagogical help since they are in a risk group with disorders and maladjustment.

Key words: maladjustment, parental conflict, children, adolescents, internalizing problems, externalizing problems

\section{Funkcjonowanie rodziny w kontekście nieprzystosowania społecznego dzieci i młodzieży}

Dzieci i młodzież jako jednostki będące w trakcie dynamicznego rozwoju biopsycho-społecznego doświadczają wielu trudności normatywnych i nienormatywnych wymagających użycia nowych strategii adaptacyjnych. Formy adaptacji mogą być zarówno pozytywne dla funkcjonowania jednostki (np. budowanie pozytywnej samooceny czy niezależności), jak i negatywne - na przykład poprzez kształtowanie zachowań ryzykownych, antyspołecz- 
nych, przyjęcie tożsamości negatywnej, a w skrajnych przypadkach - tożsamości przestępczej. Owe niekorzystne rozwiązania adaptacyjne manifestują się w postaci niedostosowania społecznego.

Ekspresji zaburzeń oraz nieprzystosowania sprzyja występowanie w środowisku wzrostu i rozwoju jednostki tak zwanych czynników ryzyka, przy jednoczesnym deficycie zasobów kompensujących ich zagrażający wpływ ${ }^{1}$. Prawdopodobieństwo występowania zachowań ryzykownych czy innych form patologii jest tym większe, im więcej działa czynników wysokiego ryzyka przy słabych zasobach kompensujących zagrożenie ${ }^{2}$. Literatura przedmiotu obfituje w opisy czynników ryzyka powstawania zaburzeń u dzieci i młodzieży - przewlekły stres czy zaniedbanie emocjonalne należą do często wymienianych, a nieprawidłowe relacje $\mathrm{w}$ systemie rodzinnym jednym $\mathrm{z}$ najczęściej analizowanych $\mathrm{w}$ literaturze psychopedagogicznej determinant wyboru niekorzystnych strategii adaptacyjnych ${ }^{3}$. Rodzina jako środowisko wychowawczo-socjalizacyjne jest rozpatrywana jako źródło wpływów oddziałujących i stymulujących lub hamujących rozwój dziecka, gdyż stanowi podstawowy teren pierwotnych doświadczeń życiowych jednostki, których wpływ na jej losy życiowe jest decydujący i niezastępowalny przez żadne inne oddziaływania. Dlatego, rodzinę traktuje się jako główne źródło potencjalnych zaburzeń zachowania, prowadzących do kształtowania się syndromu niedostosowania społecznego ${ }^{4}$. W niniejszej pracy analizie poddano występowanie konfliktów między rodzicami jako czynnik ryzyka powstania nieprzystosowania dzieci i młodzieży.

Pytka i Zacharuk dokonali analizy przyczyn zaburzeń przystosowania społecznego. Wyróżnili oni czynniki środowiskowe, biopsychiczne i sytuacyjne ${ }^{5}$. Czynniki środowiskowe dotyczą funkcjonowania jednostki w życiu społecznym, podczas którego uczy się norm, wartości i ról społecznych. O nieprzystosowaniu społecznym mówi się, kiedy jednostka nie w pełni realizuje owe normy, wzory i oczekiwania społeczne ${ }^{6}$. Najczęściej wymienia się trzy rodzaje środowisk społecznych wywierających wpływ na rozwój psychospołeczny dziecka. Są nimi: rodzina, szkoła i grupa rówieśnicza. Bar-

1 Albee, 1982, za: B. Ziółkowska, Okres dorastania. Jak rozpoznać ryzyko i jak pomagać? [w:] Psychologiczne portrety człowieka. Praktyczna psychologia rozwojowa, red. A. Brzezińska, Gdańsk 2015.

2 B. Ziółkowska, Okres dorastania.

${ }^{3}$ Por. tamże.

${ }^{4}$ E. Wysocka, Diagnoza w resocjalizacji. Obszary problemowe i modele rozwiazań w ujęciu psychopedagogicznym, Warszawa 2013, s. 199.

${ }^{5}$ L. Pytka, T. Zacharuk, Wielowymiarowa geneza zaburzeń przystosowania społecznego, [w:] Pedagogika spoteczna, red. T. Pilch, I. Leparczyk, Warszawa 1995, s. 396-417.

6 Tamże. 
dzo wiele miejsca $\mathrm{w}$ analizach teoretycznych oraz badaniach poświęca się wpływowi rodziny na przystosowanie dzieci. To rodzina ma zasadniczy wpływ na kształtowanie osobowości dziecka i jego zachowań społecznych; problemy $\mathrm{w}$ funkcjonowaniu tego systemu (np. konflikty rodzinne) będą wpływać na nieprzystosowanie dzieci z tych rodzin.

W literaturze przedmiotu $\mathrm{w}$ odniesieniu do niewłaściwych sposobów funkcjonowania tego systemu mówi się o: niewłaściwej atmosferze życia rodzinnego (braku zaspokojenia potrzeb emocjonalnych dziecka), braku dostatecznej opieki nad dzieckiem, stosowaniu niewłaściwych metod wychowawczych (np. niekonsekwencja, rygoryzm) lub funkcjonowaniu dziec$\mathrm{ka} w$ rodzinie przestępczej ${ }^{7}$. Z punktu widzenia diagnozy resocjalizacyjnej (która jest niezwykle istotna $\mathrm{w}$ odniesieniu do niedostosowania społecznego ze względu na jego konsekwencje w postaci problemów w funkcjonowaniu społecznym jednostki) jako istotne wskazuje się: niewydolność wychowawczą rodzin (postawy, style wychowania), brak zaspokojenia potrzeb w rodzinie (podstawowych i wyższego rzędu), dostarczanie negatywnych wzorców osobowych (dziedziczenie norm i wartości), negatywne (patologiczne, dewiacyjne) środowisko rodzinne (uzależnienia, przemoc, agresja, przestępczość) ${ }^{\text {. }}$.

Najczęstszymi wskaźnikami niedostosowania społecznego młodzieży są zachowania antagonistyczno-destruktywne, będące wyrazem konfliktu jednostki ze społeczeństwem. Zazwyczaj opisywane objawy to negatywne i nieadekwatne reakcje na wymagania oraz nakazy zawarte $w$ przypisywanych jej rolach społecznych, nadużywanie środków psychoaktywnych, agresja antyspołeczna, ucieczki z domu i inne' .

Analiza literatury przedmiotu pozwala na konstatację, że problemy rodzinne przyczyniają się do powstawania problemów u dzieci wychowywanych w tych rodzinach. Należy podkreślić, że współczesne modele genezy zaburzeń podkreślają wieloczynnikową etiopatogenezę zaburzeń psychicznych, jednak $w$ literaturze szeroko opisywane są przyczyny rodzinne powstawania zaburzeń w okresie dzieciństwa i adolescencji10. Istnieje na przykład wiele badań potwierdzających, że do powstawania zaburzeń lękowych $\mathrm{u}$ dzieci przyczyniają się niewłaściwe relacje rodzinne ${ }^{11}$. Wychowanie

7 H. Kołakowska-Przełomowiec, Środowisko rodzinne w świetle badań kryminologicznych, [w:] Zagadnienia przestępczości w Polsce, red. J. Jasiński, Warszawa 1975.

8 E. Wysocka, Diagnoza w resocjalizacji, s. 199.

${ }^{9}$ L. Pytka, Pedagogika resocjalizacyjna. Wybrane zagadnienia teoretyczne, diagnostyczne i metodyczne, Warszawa 2008, s. 84-85.

10 Np. P.C. Kendall, Zaburzenia okresu dzieciństwa i adolescencji. Techniki terapeutyczne dla profesjonalistów i rodziców, Sopot 2015.

11 Tamże. 
w rodzinie obarczonej alkoholizmem i przemocą jest czynnikiem ryzyka powstania zaburzeń zachowania $\mathrm{u}$ dzieci $\mathrm{w}$ postaci zachowań agresywnych $^{12}$. Kendall ${ }^{13}$ opisując przyczyny rodzinne zaburzeń zachowania dzieci podkreśla znaczenie alkoholizmu (szczególnie ojca) jako predestynującego do powstawania zaburzeń zachowania u dziecka, fizycznego krzywdzenia dziecka oraz obserwowanie przez dziecko aktów przemocy małżeńskiej. Szczególne znaczenie $\mathrm{w}$ powstawaniu zaburzeń okresu rozwojowego przypisuje się takiej patologii rodzinnej, jak na przykład zaburzenia psychiczne w rodzinie lub zachowania kryminalne ${ }^{14}$.

Według Ary'ego i współautorów, głównym mechanizmem odpowiedzialnym za powstawanie zachowań problemowych u dorastającej młodzieży jest niesprzyjający klimat $\mathrm{w}$ rodzinie, objawiający się częstymi kłótniami i konfliktami domowników, wybuchami złości i agresji w codziennych kontaktach rodzinnych. Konfliktowy klimat rodzinny uruchamia ścieżkę specyficznych procesów rozwojowych, które znacznie zwiększają prawdopodobieństwo występowania zachowań problemowych $\mathrm{w}$ okresie dojrzewania. Kolejne etapy tego procesu to: (1) konfliktowy klimat rodziny, który sprzyja, (2) powstawaniu i utrwalaniu się niekorzystnych relacji rodzice-dorastające dziecko (rodzice nie wspierają dziecka i nie angażują się w jego codzienne sprawy), (3) ten typ relacji $\mathrm{z}$ dorastającym dzieckiem utrudnia skuteczne wypełnianie funkcji rodzicielskich (brak właściwego nadzoru nad czasem wolnym, życiem towarzyskim nastolatka) i (4) sprzyja nawiązywaniu kontaktów towarzyskich z problemowymi grupami rówieśniczymi, co prowadzi do (5) podejmowania zachowań problemowych w okresie adolescencji15.

Można więc przyjąć, że problemy rodzinne będą przyczyniać się do powstawania zaburzeń emocjonalnych oraz zachowania u dzieci i młodzieży, które mogą (bez właściwej pomocy psychopedagogicznej) przyczynić się do ukształtowania się niedostosowania społecznego, a nawet działalności antyspołecznej, na przykład poprzez wchodzenie w konflikty z prawem ${ }^{16}$.

W literaturze przedmiotu istnieje wiele klasyfikacji i teorii zaburzeń zachowania oraz niedostosowania społecznego dzieci i młodzieży ${ }^{17}$. W niniej-

12 W. Badura-Madej, A. Dobrzyńska-Mesterhazy, Przemoc w rodzinie. Interwencja kryzysowa i psychoterapia, Kraków 2000; I. Pospiszyl, Przemoc w rodzinie, Warszawa 1994.

${ }^{13}$ P.C. Kendall, Zaburzenia okresu dzieciństwa $i$ adolescencji.

${ }^{14}$ I. Namysłowska, Psychiatria dzieci i młodzieży (wybrane zagadnienia), [w:] Psychiatria. Podręcznik dla studentów medycyny, red. A. Bilikiewicz, Warszawa 2001.

$15 \mathrm{Za}$ : K. Ostaszewski, Zachowania ryzykowne młodzieży w perspektywie koncepcji resilience, Warszawa 2014.

16 Por. etapy wykolejenia społecznego Cz. Czapów, Wychowanie resocjalizujące. Elementy metodyki i diagnostyki, Warszawa 1978.

${ }^{17}$ Zob. więcej B. Urban, J.M. Stanik, Resocjalizacja teoria i praktyka pedagogiczna, t. 1, Warszawa 2008, s. 155-156. 
szej pracy analizowane badania dotyczące znaczenia konfliktów między rodzicami dla przystosowania dzieci opierają się głównie na typologii Achenbacha, która nawiązuje do klasyfikacji DSM. Na podstawie trzech wersji arkuszy diagnostycznych: dla rodziców (Child Behavior Checklist), dla nauczycieli (Teacher's Report Form) oraz samooceny (Youth Self-Report) dokonywana jest ocena zachowań dziecka. W opisywanej typologii wyróżniono zachowania internalizacyjne i eksternalizacyjne. Pierwsze z nich (internalizacyjne) to zachowania nadmiernie kontrolowane (overcontrolled). Nadmierne poczucie kontroli prowadzi do głębokiej internalizacji wszelkich norm społecznych, którego następstwem jest: wycofanie, lęk oraz depresja. Takie dzieci bojaźliwie przestrzegają wszelkich zakazów, raczej są ofiarami, podlegają marginalizacji odrzucone przez rówieśników. Drugą wyróżnioną kategorię stanowią zachowania eksternalizacyjne - zachowania słabo kontrolowane (externalizing-undercontroled), "rzutowane na zewnątrz” - agresywne, buntownicze, impulsywne. Rozładowanie napięć poprzez impulsywne działania powoduje szybkie obniżenie napięcia i w konsekwencji utrwala się - co przyczynia się do braku internalizacji norm społecznych, standardów i zakazów. Istnieją także przypadki mieszane, spełniające częściowo kryteria jednego i drugiego typu ${ }^{18}$.

\section{Znaczenie konfliktów rodzicielskich dla dzieci i młodzieży}

Analizy naukowe dotyczące konfliktów rodzicielskich dotyczyły różnych obszarów funkcjonowania zarówno samych rodziców, rodziny, jak i dzieci oraz ich wzajemnych relacji. Badano, jakie aspekty sytuacji konfliktowych są szczególnie trudne dla rozwoju dzieci, jakie istnieją konsekwencje konfliktów rodzicielskich, jakie czynniki chronią przed konsekwencjami konfliktów, jakie pogłębiają trudności adaptacyjne dzieci oraz jak trudności dzieci oddziałują na relacje między rodzicami. W tej części pracy przedstawione zostaną sposoby rozumienia wpływu rodzicielskich sytuacji konfliktowych na dzieci, które stały się podstawą naukową prowadzonych badań w tej dziedzinie.

Znaczenie konfliktów rodzicielskich w sposobie funkcjonowania rodziny stanowi jedną z głównych idei koncepcji systemowych ${ }^{19}$. Dziecko może zo-

18 Tamże.

19 Zob. więcej na temat kompetencji komunikacyjnych w diadzie: K. Kuryś, Porozumienie w matżeństwie jako narzędzie rozumienia, [w:] Komunikacja jako narzędzie (po)rozumienia we wspólnotach spotecznych, red. A. Mitręga, I. Jagoszewska, Toruń 2012, s. 17-28; tegoż, Kompetencja komunikacyjna diady matżeńskiej jako wartość $i$ zasób w biografii systemu rodzinnego, [w:] Wartości 
stać wciągnięte w konflikt rodziców lub stanowić jego stronę, w celu zredukowania stresu i napięcia $\mathrm{w}$ rodzinie. Zaangażowanie dziecka $\mathrm{w}$ konflikt może przybierać różne formy. Na przykład, rodzice mogą winić dziecko za ich konflikt lub skupić się na zachowaniu dziecka w celu uniknięcia rozwiązania problemów $\mathrm{w}$ małżeństwie - proces znany jest jako poszukiwanie kozła ofiarnego. Alternatywnie, rodzice mogą starać się sprzymierzyć z dzieckiem przeciwko drugiemu rodzicowi, tworząc międzypokoleniową koalicję, w której dziecko ma zbyt bliskie lub uwikłanie relacje z jednym rodzicem i zbyt odległy związek z drugim. Wzór ten może być szczególnie prawdopodobny $\mathrm{w}$ kontekście rozwodu, jeśli rodzice walczą o miłość i lojalność swoich dzieci. Mogą oni źle wypowiadać się na temat swojego eksmałżonka lub używać dzieci do przekazywania mu wiadomości lub uzyskiwania informacji na jego temat ${ }^{20}$.

Nawiązując do koncepcji przywiązania, Fincham, Grych i Osborne twierdzą, że obserwowanie, jak rodzice traktują siebie kiedy się ze sobą nie zgadzają, ma duże szanse wpłynąć na ukształtowanie wewnętrznych modeli relacji międzyludzkich u dzieci. Owe wzorce relacji będą mieć konsekwencje w budowaniu innych relacji społecznych ${ }^{21}$.

Dzieci, których rodzice rozwiązują konflikty przez próby kontroli, zastraszania i dominacji mogą wykorzystywać podobne strategie (w odpowiednich dla wieku formach) z rówieśnikami. Ważne jest bowiem również społeczne uczenie się zachowań agresywnych. Modelowanie może doprowadzić do powstania takich problemów eksternalizacyjnych u dzieci i młodzieży, jak na przykład impulsywność, agresja, zachowania opozycyjnobuntownicze 22 .

Obserwowanie małżeńskiego konfliktu może także wpłynąć na rozwijającą się umiejętność dzieci do regulowania ich uczuć. Konflikt pomiędzy rodzicami może być bardzo angażujący emocjonalnie i stanowi stąd wyzwanie dla dziecięcej regulacji emocji. Problemy z emocjonalną regulacją mogą być manifestowane zarówno poprzez objawy eksternalizacyjne (np. impulsywność, agresja), jak też internalizacyjne (np. lęk i depresja), co może zakłócać przystosowanie międzyrówieśnicze ${ }^{23}$.

w komunikacji różnych grup społecznych, red. M. Baryluk, M. Wawrzak-Chodaczek, Torun 2009, s. 67-77.

20 J.H. Grych, Interparental conflict as a risk factor for child maladjustment: Implications for the Development of Prevention Programs, Family Court Review, 2005, 43, 1, s. 97-108.

${ }^{21}$ F.D Fincham, J.H Grych, L.N. Osborne, Does Marital Conflict Cause Child Maladjustment? Directions and Challenges for Longitudinal Research, Journal of Family Psychology, 1994, 8, 2, s. $128-140$.

22 Tamże.

${ }^{23}$ Tamże. 
Oceny dzieci odnośnie konfliktu mogą mieć również konsekwencje dla ich przystosowania, szczególnie dla powstania objawów internalizacyjnych. Te, które obwiniają się o problemy rodziców albo odczuwają bezradność w obliczu ich konfliktów mogą rozwijać niskie poczucie własnej wartości albo zaburzenia nastroju. Dzieci czujące zagrożenie i niezdolne do poradzenia sobie z tym problemem będą doświadczać ciągłego niepokoju24.

Małżeński konflikt może być także określony jako bodziec stresowy, który połączony z innymi bodźcami stresowymi w życiu dziecka prowadzi do rozwoju problemów w przystosowaniu ${ }^{25}$.

Prowadzone analizy opierały się również na hipotezie, że konflikt rodzicielski „rozlewa się" na relację rodzic-dziecko. Rodzicielstwo cierpi, kiedy pary są uwikłane $\mathrm{w}$ konflikt, jako że rodzice mogą stać się wrodzy, agresywni lub wycofani $\mathrm{w}$ relacji $\mathrm{z}$ dziećmi i bardziej niespójni $\mathrm{w}$ ich dyscyplinowaniu ${ }^{26}$.

Konflikt może mieć większy wpływ na wycofanie z relacji w rodzinach rozwiedzionych szczególnie dla rodziców niemieszkających wspólnie $\mathrm{z}$ dzieckiem ${ }^{27}$. Mogą oni ograniczać czas spędzany z dziećmi, w celu uniknięcia konfliktów $\mathrm{z}$ ich byłym współmałżonkiem. Buchanan, Maccoby i Dornbusch stwierdzają, że młodzież z rozwiedzionych rodzin zgłasza mniej uczuć bliskości do swoich ojców, z którymi nie mieszka ${ }^{28}$.

Prowadzono także badania zgodne $\mathrm{z}$ „hipotezą zakłócenia dyscypliny" 29 (disrupted discipline hypothesis) oraz "hipotezą efektu ubocznego"30 (spillover hypothesis), w których konflikt i niepokój w związku małżeńskim prowadzą do takich negatywnych zachowań rodzicielskich, jak brak konsekwencji, odrzucenie, wrogość i raniąca dyscyplina. Na przykład, Caspi i Elder ${ }^{31}$ stwierdzili, że konflikt małżeński wpływa na dziecięce problemy pośrednio poprzez nieoptymalne praktyki wychowawcze, szczególnie w niespójnych strategiach karania używanych przez rodziców. Harold i Conger ${ }^{32}$ uważają natomiast, że małżeński konflikt wpływa pośrednio na wzrost adolescencyj-

24 Tamże.

25 Tamże.

${ }^{26} \mathrm{~J} . \mathrm{H}$. Grych, Interparental conflict as a risk factor, s. 97-108.

27 Tamże.

${ }^{28}$ Buchanan, Maccoby i Dornbusch (1996), za: tamże.

${ }^{29}$ R.E. Emery, Interparental conflict and the children of discord and divorce, Psychological Bulletin, 1982, 92, s. 310-330.

30 A. Engfer, The interrelatedness of marriage and the mother-child relationship, [w:] Relationships within families: mutual influences, eds. R.A Hinde, J. Stevenson-Hinde, Oxford 1988, s. 104-118.

31 A. Caspi, G.H. Elder Jr., Emergent family patterns: The intergenerational construction of problem behavior and relationships, [w:] Relationships within families: Mutual influences, red. R.A. Hinde, J. Stevenson-Hinde, New York 1988, s. 218-240.

32 G.T. Harold, R.D. Conger, Marital conflict and adolescent distress: The role of adolescent awareness, Child Development, 1997, 68, s. 330-350. 
nych problemów internalizacyjnych i eksternalizacyjnych poprzez wrogie nieprzyjazne wychowanie.

Zgodnie z hipotezą „utraty miłości” (loss of love), problemy małżeńskie rodziców zmniejszają ich ciepłe i wspomagające zachowanie rodzicielskie, które z kolei prowadzi do problemów w dostosowaniu dzieci i młodzieży ${ }^{33}$.

\section{Konflikt rodzicielski \\ jako czynnik ryzyka powstawania zaburzeń przystosowania - analiza wybranych wyników badań}

Prowadzone liczne badania mają na celu sprawdzenie konsekwencji rodzicielskiego konfliktu dla adaptacji dzieci. Cytowane poniżej odnoszą się do objawów eksternalizacyjnych i internalizacyjnych jako problemów z przystosowaniem dzieci i młodzieży. Do pomiaru zaburzeń stosuje się na przykład Child Behavior Checklist, Teacher's Report Form, Youth Self-Report, która jest jedną z najbardziej powszechnie używanych skal pomiaru dostarczającą zarówno ocen rodziców, nauczycieli, jak i dzieci34.

Dzieci doświadczające silnych konfliktów rodzicielskich są zagrożone rozwojem szeregu emocjonalnych i behawioralnych problemów zarówno podczas dzieciństwa, jak i w wieku późniejszym ${ }^{35}$. Wykazano, że istnieje silny związek pomiędzy konfliktem rodzicielskim a nieprzystosowaniem dzieci i, jak dowodzą niektórzy naukowcy, jest on dwa razy silniejszy niż związek między nieprzystosowaniem a rozwodem ${ }^{36}$. W rzeczywistości, niektórych negatywnych skutków przypisywanych rozwodom można doszukiwać się w konflikcie, który często poprzedza decyzję o rozstaniu i następnie towarzyszy rozpadowi życia małżeńskiego ${ }^{37}$.

33 R.E. Emery, K.D. O'Leary, Children's perceptions of marital discord and behavior problems of boys and girls, Journal of Abnormal Child Psychology, 1982, 10, s. 11-24.

${ }^{34}$ T.J. Dishion, Cross-Setting Consistency in Early Adolescent Psychopathology: Deviant Friendships and ProblemBehavior Sequelae, Journal of Personality, 2000, 68, s. 6.

35 J.H. Grych, Interparental conflict as a risk factor, s. 97-108; J.H. Grych, F.D. Fincham, Marital conflict and children's adjustment: A cognitive-contextual framework, Psychological Bulletin, 1990, 108, s. 267-290; tychże, Children's appraisals of marital conflict: Initial investigations of the cognitive-contextual framework, Child Development, 1993, 64, s. 215-230; tychże, Interparental conflict and child development: Theory, research, and applications, New York 2001; J.B. Kelly, Children's adjustment in conflicted marriages and divorce: A decade review of research, J Am Acad Child Adolesc Psychiatry, 2000, 39, s. 963-973.

${ }^{36}$ P.R Amato, B. Keith, Parental divorce and the well-being of children: A meta-analysis, Psychological Bulletin, 1991, 110, s. 26-46.

37 R.E. Emery, Marriage, divorce, and children's adjustment; E.M. Hetherington, M. Bridges, G.M. Insabella, What matters? What does not? Five perspectives on the association between marital transitions and children's adjustment, American Psychologist, 1998, 53, s. 167-184. 
W licznych badaniach dowiedziono związków pomiędzy konfliktem rodziców a niedostosowaniem ich dzieci. Na przykład, badanie prowadzone przez Cui, Donnella, Conger ${ }^{38}$ polegało na analizie wzajemnych powiązań między małżeńskim funkcjonowaniem a niedostosowaniem młodzieży. Podłużnymi badaniami objęto 451 wczesnych nastolatków i ich rodziny. Wyniki wskazują, że konflikty rodzicielskie podczas wychowywania dzieci powodują u dorastających objawy depresji i przestępczości. $\mathrm{Z}$ kolei, te młodzieńcze problemy pogarszają konflikty między rodzicami w obszarze wychowywania dzieci. Ponadto, konflikty dotyczące wychowywania dzieci były powiązane bardziej z ogólnym małżeńskim niezadowoleniem i problemami z przystosowaniem u adolescentów.

Kolejne badania Cui i Conger ${ }^{39}$ miały na celu sprawdzenie mediującego i moderującego efektu zachowań rodzicielskich na związki pomiędzy rodzicielskimi problemami i adolescencyjnym niedostosowaniem. Rozszerzenie wcześniejszych badań za pomocą prospektywnego, podłużnego projektu badawczego z użyciem multiinformatora, to badanie 451 adolescentów i ich rodzin. Projekt pokazuje, że szerokie spektrum rodzicielskich zachowań pośredniczy $\mathrm{w}$ relacji między problemami małżeńskimi i funkcjonowaniem adolescentów. Wyniki sugerują również, że zarówno małżeńskie konflikty, jak i stres w małżeństwie są szkodliwe dla młodzieży. Co więcej, nie tylko jeden $\mathrm{z}$ aspektów, ale szeroki zakres zachowań rodzicielskich łączy problemy małżeńskie z młodzieńczym niedostosowaniem.

Problematyka doświadczanego przez małżonków stresu podejmowana była również w badaniach Davies, Dumenci i Windle ${ }^{40}$. Stwierdzili oni, że stres którego doświadczają matki w małżeństwie jest predyktorem adolescencyjnych objawów eksternalizacyjnych i bezpośrednio oraz pośrednio przewiduje adolescencyjne objawy depresji poprzez depresyjne symptomy u matek.

Z kolei, badania prowadzone przez Davies, Sturge-Apple, Bascoe i Cummings ${ }^{41}$ miało na celu sprawdzenie zależności pomiędzy rodzicielskim kon-

${ }^{38}$ M. Cui, M.B. Donnellan, R.D. Conger, Reciprocal Influences Between Parents' Marital Problems and Adolescent Internalizing and Externalizing, Behavior Developmental Psychology, 2007, 43, 6, s. 1544-1552.

${ }^{39}$ M. Cui, R.D. Conger, Parenting Behavior as Mediator and Moderator of the Association Between Marital Problems and Adolescent Maladjustment, Journal of Research on Adolescence, 2008, 18(2), s. 261-284.

40 P.T Davies, L. Dumenci, M. Windle, The interplay between maternal depressive symptoms and marital distress in the prediction of adolescent adjustment, Journal of Marriage and the Family, 1999, 61, s. 238-254.

${ }^{41}$ P.T. Davies i in., The Legacy of Early Insecurity Histories in Shaping Adolescent Adaptation to Interparental Conflict, Child Development, 2014, 85, 1, s. 338-354. 
fliktem, młodzieńczym emocjonalnym brakiem pewności siebie i psychicznymi problemami adolescentów. Badaniami objęto 230 rodzin, kiedy dzieci były $\mathrm{w}$ pierwszej klasie (średnia wieku dzieci $=7$ lat). Wyniki wskazały, że konflikty między rodzicami wiążą się ze wzrostem młodzieńczego emocjonalnego braku pewności siebie, który jest z kolei predyktorem późniejszych psychicznych problemów. Dziecięcy brak pewności siebie implikował młodzieńcze nieprzystosowanie nawet po 5 latach.

Podłużne badania prowadzone przez Blodgett Salafia, Gondoli oraz Grundy ${ }^{42}$ dotyczyły związków pomiędzy dystresem matek, małżeńskimi konfliktami a wczesnymi młodzieńczymi symptomami - eksternalizacyjnymi i internalizacyjnymi podczas przechodzenia dzieci do okresu dojrzewania. Trzyletnie dane z raportów zostały pozyskane od 136 zamężnych matek i ich dzieci. Badania rozpoczynały się, kiedy dzieci były w 5 klasie. Wyniki z ocen matek wskazały, że małżeński konflikt jest mediatorem związku pomiędzy wcześniejszym matczynym cierpieniem psychicznym a późniejszymi wczesnoadolescencyjnymi objawami eksternalizacyjnymi i internalizacyjnymi. Dla wczesnych nastolatków mediujący wzór konfliktów rodzicielskich został dowiedziony dla powstawania zachowań eksternalizacyjnych.

Badania wiążące problematykę konfliktów rodzinnych $\mathrm{z}$ płcią dzieci i rodziców prowadzili Schwarz i Getter ${ }^{43}$. Uzyskane wyniki wykazały, że wskaźnikiem neurotyzmu i poważnej psychopatologii dla późnych adolescentów mogą być ich oceny konfliktu rodziców. Jednakże okazało się, że znaczenie ma także płeć adolescenta i płeć dominującego rodzica. Neurotyzm u córek może być wynikiem pochodzenia z wysoko konfliktowej rodziny z dominującym ojcem, a neurotyzm synów - z wysoko konfliktowej rodziny z dominującą matką. Potrójne oddziaływanie konfliktów, dominacji rodziców i płci dziecka przyczynia się do powstawania neurotyzmu i poważnej psychopatologii, ale nie do przewidywania niedostosowania się do norm społecznych. Predyktorem nieprzystosowania społecznego jest wyłącznie konflikt rodzicielski.

Konsekwencje konfliktów rodzicielskich mogą sięgać również problemów ich dzieci już w okresie dorosłości. Jak wykazano, oprócz okazywania wyższych poziomów niepokoju, depresji i destrukcyjnych zachowań, dzieci będące świadkiem wrogości i agresji ich rodziców mają duże szanse na podejmowanie znieważających zachowań wobec romantycznych partnerów

42 E.H. Blodgett Salafia, D.M. Gondoli, A.M. Grundy, Marital Conflict as a Mediator of the Longitudinal Connections between Maternal Emotional Distress and Early Adolescent Maladjustment, Journal Child and Family Studies, 2008, 17, s. 928-950.

43 J.C. Schwarz, H. Getter, Parental Conflict and Dominance in Late Adolescent Maladjustment: A Triple Interaction Model, Journal of Abnormal Psychology, 1980, 89, 4, s. 573-578. 
$\mathrm{w}$ adolescencji i wieku dojrzałym ${ }^{44}$ oraz są bardziej zagrożone rozwodem i nieprzystosowaniem $\mathrm{w}$ wieku dojrzałym ${ }^{45}$.

Zdaniem Ostaszewskiego, który dokonał analizy czynników ryzyka powstawania zachowań antyspołecznych wśród młodzieży, należy do nich niestabilność i konfliktowy charakter życia rodzinnego, w tym przede wszystkim gwałtowne kłótnie rodziców i stosowanie przemocy fizycznej w relacjach małżeńskich lub partnerskich, separacja lub rozwód rodziców ${ }^{46}$.

W obliczu tak poważnych konsekwencji, jakich doświadczają dzieci wychowywane $\mathrm{w}$ rodzinach konfliktowych podejmowane są działania pomocowe, na przykład w sytuacji rozwodu. Programy pomocy dla rodzin mogą być czynnikiem chroniącym, kompensującym negatywny wpływ czynników ryzyka. Grych twierdzi, że pomimo iż programy psychoedukacyjne dla rodzin są dostępne i na przykład zalecane przez sądy rodzinne, badania ich skuteczności są rzadkie ${ }^{47}$. Podkreśla się zazwyczaj, iż prewencja powstawania zaburzeń $u$ dzieci i młodzieży ze względu na problemy rodzinne powinna być wieloaspektowa ${ }^{48}$. Grych analizował badania nad wpływem rodzicielskiego konfliktu na dzieci oraz badał edukacyjne programy zaprojektowane by redukować konflikt po rozwodzie. Dotyczyły one rodzin zastępczych i wskazały, że programy prewencyjne dla rodziców będą najbardziej skuteczne dla adaptacji dzieci do rozwodu, jeśli pomogą obniżyć poziom niszczącego konfliktu między rodzicami. Istotne jest także budowanie dobrych stosunków między przybraną mamą a dzieckiem. Ponadto, ważne jest powstrzymywanie dzieci przed angażowaniem się do rodzicielskich napięć i sporów. Programy dla dzieci mają duże szanse bycia najbardziej skutecznymi, jeśli pomagają dzieciom nauczyć się sposobów radzenia sobie z sytuacjami, w których czują się wciągane $\mathrm{w}$ koalicję z jednym rodzicem przeciwko drugiemu i uwalniają od poczucia odpowiedzialności za rodzicielskie problemy ${ }^{49}$.

W niniejszej pracy dokonano analizy wybranych badań dotyczących wpływu konfliktów między rodzicami na problemy doświadczane przez ich dzieci. Przywołane dane wykazały, że konflikt rodzicielski stanowi czynnik ryzyka powstawania nieprzystosowania społecznego (rozumianego jako

44 C. Wekerle, D.A. Wolfe, Dating violence in mid-adolescence: Theory, significance, and emerging prevention initiatives, Clinical Psychology Review, 1999, 19, s. 435-456.

45 P.R. Amato, J.M. Sobolewski, The effects of divorce and marital discord on children's psychological well-being, American Sociological Review, 2001, 66, s. 900-921.

46 K. Ostaszewski, Zachowania ryzykowne młodzieży.

47 J.H. Grych, Interparental conflict as a risk factor, s. 97-108.

48 E.H. Blodgett Salafia, D.M. Gondoli, A.M. Grundy, Marital Conflict as a Mediator of the Longitudinal Connections, s. 928-950.

49 J.H. Grych, Interparental conflict as a risk factor, s. 97-108. 
powstawanie zaburzeń internalizacyjnych i eksternalizacyjnych). Trudności, których doświadczają dzieci mogą pogłębić konflikt między partnerami szczególnie w obszarze oddziaływań wychowawczych. W sytuacji, w której, jak wykazują wyniki badań, stres w rodzinie i rozwiązywanie problemów poprzez kłótnie i agresję między rodzicami niesie ze sobą tak poważne problemy doświadczane przez wychowywane w tych rodzinach dzieci, powstaje potrzeba tworzenia programów pomocowych skierowanych do członków systemu rodzinnego oraz ich rzetelna ewaluacja. Zwolennicy pozytywnej profilaktyki uznają, że istotne jest wzmacnianie czynników chroniących i rozwijanie zasobów, przy jednoczesnym redukowaniu ryzyka ${ }^{50}$. Powstaje także pytanie: jakie formy pomocy psychopedagogicznej byłyby najbardziej skuteczne dla dzieci i młodzieży narażonych na wpływ rodzicielskiego konfliktu? Obszar czynników ryzyka powstawania zaburzeń oraz czynników chroniących powinien być szerzej i dogłębniej badany, wzbogacając praktykę pomocową o dowody empiryczne, prowadząc w konsekwencji do badań nad skutecznością oddziaływań psychopedagogicznych i wprowadzając dobrą praktykę w obszarze stosowanych interwencji, metod i form pomocy.

\section{BIBLIOGRAFIA}

Amato P.R., Keith B., Parental divorce and the well-being of children: A meta-analysis, Psychological Bulletin, 1991, 110.

Amato P.R., Sobolewski J.M., The effects of divorce and marital discord on children's psychological well-being, American Sociological Review, 2001, 66.

Badura-Madej W., Dobrzyńska-Mesterhazy A., Przemoc w rodzinie. Interwencja kryzysowa i psychoterapia, Wydawnictwo UJ, Kraków 2000.

Blodgett Salafia E.H., Gondoli D.M., Grundy A.M., Marital Conflict as a Mediator of the Longitudinal Connections between Maternal Emotional Distress and Early Adolescent Maladjustment, Journal Child and Family Studies, 2008, 17.

Caspi A., Elder G.H. Jr., Emergent family patterns: The intergenerational construction of problem behavior and relationships, [w:] Relationships within families: Mutual influences, eds R.A. Hinde, J. Stevenson-Hinde, Oxford University Press, New York 1988.

Cui M., Conger R.D., Parenting Behavior as Mediator and Moderator of the Association Between Marital Problems and Adolescent Maladjustment, Journal of Research on Adolescence, $2008,18(2)$.

Cui M., Donnellan M.B., Conger R.D., Reciprocal Influences Between Parents' Marital Problems and Adolescent Internalizing and Externalizing, Behavior Developmental Psychology, 2007, 43, 6 .

Czapów Cz., Wychowanie resocjalizujące. Elementy metodyki i diagnostyki, PWN, Warszawa 1978.

${ }^{50}$ K. Ostaszewski, Zachowania ryzykowne młodzieży. 
Davies P. T, Dumenci L., Windle M., The interplay between maternal depressive symptoms and marital distress in the prediction of adolescent adjustment, Journal of Marriage and the Family, 1999, 61.

Davies P.T., Sturge-Apple M.L., Bascoe S.M.E., Cummings M., The Legacy of Early Insecurity Histories in Shaping Adolescent Adaptation to Interparental Conflict, Child Development, 2014, 85, 1.

Dishion T.J., Cross-Setting Consistency in Early Adolescent Psychopathology: Deviant Friendships and ProblemBehavior Sequelae, Journal of Personality, 2000, 68.

Emery R.E., Interparental conflict and the children of discord and divorce, Psychological Bulletin, 1982, 92.

Emery R.E., Marriage, divorce and children's adjustment, CA: Sage, Newbury Park 1999.

Emery R.E., O'Leary K.D., Children's perceptions of marital discord and behavior problems of boys and girls, Journal of Abnormal Child Psychology, 1982, 10.

Engfer A., The interrelatedness of marriage and the mother-child relationship, [w:] Relationships within families: mutual influences, red. R.A Hinde, J. Stevenson-Hinde, Oxford University Press, Oxford 1988.

Fincham F.D., Grych J.H., Osborne L.N., Does Marital Conflict Cause Child Maladjustment? Directions and Challenges for Longitudinal Research, Journal of Family Psychology, 1994, $8,2$.

Grych J.H., Interparental conflict as a risk factor for child maladjustment: Implications for the Development of Prevention Programs, Family Court Review, 2005, 43, 1.

Grych J.H., Fincham F.D., Marital conflict and children's adjustment: A cognitive-contextual framework, Psychological Bulletin, 1990, 108.

Grych J.H., Fincham F.D., Children's appraisals of marital conflict: Initial investigations of the cognitive-contextual framework, Child Development, 1993, 64.

Grych J.H., Fincham F.D., Interparental conflict and child development: Theory, research, and applications, Cambridge University Press, New York 2001.

Harold G.T., Conger R.D., Marital conflict and adolescent distress: The role of adolescent awareness, Child Development, 1997, 68.

Hetherington E.M., Bridges M., Insabella G.M., What matters? What does not? Five perspectives on the association between marital transitions and children's adjustment, American Psychologist, 1998, 53.

Kelly J.B., Children's adjustment in conflicted marriages and divorce: A decade review of research, J Am Acad Child Adolesc Psychiatry, 2000, 39.

Kendall P.C., Zaburzenia okresu dzieciństwa i adolescencji. Techniki terapeutyczne dla profesjonalistów i rodziców, Gdańskie Wydawnictwo Psychologiczne, Sopot 2015.

Kołakowska-Przełomowiec H., Środowisko rodzinne w świetle badań kryminologicznych, [w:] Zagadnienia przestępczości w Polsce, red. J. Jasiński, Wydawnictwo Prawnicze, Warszawa 1975.

Kuryś K., Kompetencja komunikacyjna diady małżenskiej jako wartość i zasób w biografii systemu rodzinnego, [w:] Wartości w komunikacji różnych grup społecznych, red. M. Baryluk, M. Wawrzak-Chodaczek, Wydawnictwo Adam Marszałek, Torun 2009.

Kuryś K., Porozumienie w matżeństwie jako narzędzie rozumienia, [w:] Komunikacja jako narzędzie (po)rozumienia we wspólnotach społecznych, red. A. Mitręga, I. Jagoszewska, Wydawnictwo Adam Marszałek, Torun 2012.

Namysłowska I., Psychiatria dzieci i młodzieży (wybrane zagadnienia), [w:] Psychiatria. Podręcznik dla studentów medycyny, red. A. Bilikiewicz, Wydawnictwo Lekarskie PZWL, Warszawa 2001. 
Ostaszewski K., Zachowania ryzykowne młodzieży w perspektywie koncepcji resilience, Instytut Psychiatrii i Neurologii, Warszawa 2014.

Pospiszyl I., Przemoc w rodzinie, Wydawnictwa Szkolne i Pedagogiczne, Warszawa 1994.

Pytka L., Pedagogika resocjalizacyjna. Wybrane zagadnienia teoretyczne, diagnostyczne i metodyczne, Wydawnictwo Akademii Pedagogiki Specjalnej, Warszawa 2008.

Pytka L., Zacharuk T., Wielowymiarowa geneza zaburzeń przystosowania społecznego, [w:] Pedagogika społeczna, red. T. Pilch, I. Leparczyk, Wydawnictwo Akademickie Żak, Warszawa 1995.

Schwarz J.C., Getter H., Parental Conflict and Dominance in Late Adolescent Maladjustment: A Triple Interaction Model, Journal of Abnormal Psychology, 1980, 89, 4.

Urban B., Stanik J.M., Resocjalizacja teoria i praktyka pedagogiczna, t. 1, Wydawnictwo Naukowe PWN, Warszawa 2008.

Wekerle C., Wolfe D.A., Dating violence in mid-adolescence: Theory, significance, and emerging prevention initiatives, Clinical Psychology Review, 1999, 19.

Wysocka E., Diagnoza w resocjalizacji. Obszary problemowe i modele rozwiązań w ujęciu psychopedagogicznym, Wydawnictwo Naukowe PWN, Warszawa 2013.

Ziółkowska B., Okres dorastania. Jak rozpoznać ryzyko i jak pomagać? [w:] Psychologiczne portrety człowieka. Praktyczna psychologia rozwojowa, red. A. Brzezińska, Gdańskie Wydawnictwo Psychologiczne, Gdańsk 2015. 